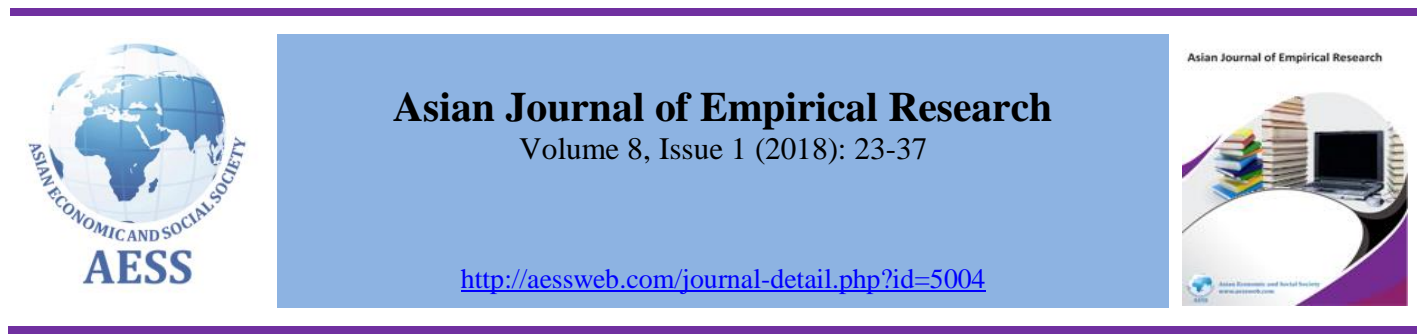

\title{
Corporate finance strategy via Tunisian venture capital organisms
}

\section{Houda Dziria ${ }^{\mathrm{a}}$, Anis Jarboui ${ }^{\mathrm{b}}$}

a Department of Financial and Accounting, Faculty of Economics and management of Sfax, University of Sfax,Tunisia. $\ \underline{\text { houdadziri2017@gmail.com }}$

${ }^{\mathrm{b}}$ Department of Financial and Accounting, High Institute of Business Administration, Universities of Sfax, Tunisia.

\section{ARTICLE HISTORY:}

Received: $15-$ Nov-2017

Accepted: 03-Jan-2018

Online available: $16-\mathrm{Jan}-2018$

\section{Keywords:}

Attitude towards risk, Selection criteria, Tunisian based companies, Venture capital financing mode

\begin{abstract}
The present research work is designed to examine the Tunisian corporate case financing strategy as undertaken by the venture capital institutions, on the basis of some criteria applied during the selection process. After discussing the theoretical relationship between the venture capitalist and the entrepreneur, we are advancing an empirical model testing the influence of the venture capitalist' selection criteria on the acceptance to finance the enterprise. Overall, the study's reached finding, as conducted on a sample of 41 venture capital companies operating up until the end of the year 2016. In fact, the study have revealed well the significantly impact of certain adopted criteria in relation to the other criteria and it maintains that the venture capitalist' attitude towards the investment risk.
\end{abstract}

\section{Contribution/ Originality}

This paper find reflects the venture capital companies' aversion to the decisive power the contractor might have. In addition, the in-capital investor approach should, therefore, be rather operational in formulating the appropriately fit strategy, through the investors' disposition to provide management with the necessary skills, knowledge as well as their maintained professional relationships responding to the financial needs.

DOI: $10.18488 /$ journal.1007/2018.7.1/1007.1.23.37

ISSN (P): 2306-983X, ISSN (E): 2224-4425

CrossMark

How to cite: Houda Dziri and Anis Jarboui (2018). Corporate finance strategy via Tunisian venture capital organisms. Asian Journal of Empirical Research, 8(1), 23-37.

(C) 2018 Asian Economic and Social Society. All rights reserved 


\section{INTRODUCTION}

It is worth highlighting that companies appealing to the investment capital funding mode are generally unlisted enterprises and, consequently, not subjected to any financial information relating pressure. Thence, the capital investor does not prove to withhold sufficiently satisfying information regarding the company, which is likely to bring about an increasing greater adverse selection risk, varying according to the firm's development stage (start-up, expansion, leveraged buyout), the activity sector and even its characteristics as well as management crew (Cyr, 2008; Alexander and Peter, 2013). In fact, companies which have recourse to the venture capital institutions as funding sources are most often characterized with high risky structures (Finucane et al., 2000; Jennifer et al., 2009; wood and Wright, 2010; Goergen et al., 2011 and MacMillan et al., 1985). Owing to such marking features, venture capitalists are usually supposed to assess the eventual risk level prior to opting and setting up the choice for their investments. Actually, the investment opportunities, assessment stage goes through a set of criteria likely to investment projects acceptance or refusal probability (MacMillan et al., 1987; Zacharakis and Meyer, 1998; Kaplan and Stromberg, 2000; Justine et al., 2015; Kisfalvi, 2002). In practice the venture capital institutions' applied criteria are numerous. With regard to our study case, and particularly the Tunisian context, the selection criteria are categorized into three major groups, namely, the contractor related criteria, the venture capitalist relevant criteria and along with those relating to the company.

\section{METHODOLOGICAL ASPECT}

\subsection{Research instrument}

At this level, the questionnaire methodology is chosen to serve as the appropriate data collection means. The study sample encloses the entirety of venture investment companies operating. It is worth noting, in this respect, that up until 2016, there have been some 45 venture capital companies, to which an administered questionnaire has been addressed, bearing short and concise questions. Noteworthy, however is that the number of responses received has not exceeded 41.

On formulation and designing the questionnaire content, two major facts have been considered, namely, that the questions should be clear and simple, and that they need be as concise as possible, in a bid to safeguard and ensure the receiver's intention to respond. To further facilitate the response task, a give rank scale involving five categories, ranging from 1 to 5, has also been provided, to help determine the degree of importance degree likely to be accorded to each selection criterion, by just ticking the appropriate column to select prospective visions.

\subsection{Literature review and research hypotheses}

Based on previously conducted studies, we consider identifying the influence of criteria applied by the venture capital companies on the acceptance decision to finance a certain company. In this context, some criteria will be examined, namely, the entrepreneur's professional competence, the venture capitalist's professional competence, the venture capitalist /entrepreneur assistance procedure, the company's capital size, the company's maturity stage, the company's innovation and creativity aspect.

\subsubsection{The entrepreneur's professional competence}

The hierarchy of the entrepreneur's related criteria appears to vary from a study to another. For instance, the competence and ability to acquire a significant market share criteria occupies the 6th position in the works conducted by Landstrom (1992) elaborated study, it occupies the 24th position among the 34 tested criteria.

Based on the works elaborated by Zopounidis (1987), Rosenbush et al. (2013), Mayer et al. (2005), Bechmann et al. (2007); Stevenot (2006), Yan et al. (2015) and Myers and Majluf (1984), the major criterion applied in selecting companies undertaken by the venture capitalists is that related to the entrepreneur's professional quality. On the basis of this observation, the following assumption can be formulated: 
H1: The entrepreneur's professional competence is the most important criterion applied by the Tunisian venture capital investment companies for selecting the potential project funding company.

\subsubsection{The venture capitalist's professional competence}

Accepting to fund the project and taking the risk depend highly on a number of variables, such as the venture capital organization's maturity and experience. A reference to the works conducted by Manigart et al. (1997), Franzke et al. (2004), Dimov et al. (2007) reveals well that, through investigating a series of perceived risk measures and an overall risk taking propensity undertaking, the authors have been able to deduce that the executives of the most mature companies detain a high risk aversion character. The venture capital company professional competence as investigated in the present study, it has depicted through the number of experience years the organism spent in funding venture capital organizations. This way seems worth advancing:

$\mathrm{H} 2$ : The more important the venture capital professional competence is the lower; the acceptance rate to finance companies proves to be is weak.

\subsubsection{The venture capitalist /entrepreneur assistance procedure}

At this stage, our aim venture lies in studying the frequent interactions and contacts between both intervening parties and their impact on the company's funding selection. In this regard, Dimov et al. (2007) as well as Barney et al. (1994), have discovered that the face to face interaction appears to play a considerable role on the trust worthiness intention between the investor and the entrepreneur. Actually, the research work is intended to go further in scope to exceed the general framework so as to tackle the venture capital framework and to exceed the term trust between both undertaking parties to rather check the acceptance issue of financing the business. As a matter of fact, the amount of information as analyzed by the investor on investigating a particular investment project has a crucially significant effect on either rejecting or selecting of the applicant company. What makes the project study's temporal factor considered, as one of the major selection process involved variables. In this respect, Wright and Robbie (1996) tend to demonstrate that capital investors prove to accord a great deal of importance to the negotiation and discussion they undertake with the contractor throughout their selection process of the most appropriately convenient worth funding enterprises. Talks with the investor provide an opportunity for the entrepreneur to put forward convincing arguments and highlight or expose his objectives. Hence, the following assumption could be formulated:

H3: The venture capital companies/ Entrepreneur assistance procedure has a positive effect on the acceptance decision to be funded by the venture capital companies.

\subsubsection{The firm's capital size}

With respect to the present work, the company's capital size or capacity is defined through the amount of its equity as well as its previously concluded sales' rates (if any).

The existence of a significant equity could well help in reassuring the venture capital professionals; as such a capital should stand as a manifestation of confidence already expressed by the outside parties and as a sign of the founders' capacity to insert networks in their work, thus representing a reliable convincing factor to private investors. As for the companies, especially the already established ones, the concluded sales, would stand rate as a bear witness sign testifying the competence and experience skills its leaders enjoy, which is likely to positively influence the investor's intention of the investor to opt for selecting the company (Pagano and Volpin, 2005; Shepherd and Zachrakis, 2002; Stiglitz and Weiss, 1981; Houben, 2002; Hall and Hoffer, 1993 and Wright et al., 2009). Hence, the following hypothesis may well be proposed:

H4: The firm capital size has a positive effect on the acceptance decision to be funded by the venture capital companies. 


\subsubsection{The firm's maturity stage}

A mature business and a rather aged one are more likely to provide the venture capitalist with a somewhat clear insight and visibility as to its history and evolution stages (Jengfang et al., 2012). Hence, the following hypothesis could be drawn:

H5: The firm reached maturity stage has a positive effect on the acceptance decision to be funded by the venture capital companies.

\subsubsection{The firm's innovation and creativity aspect}

Among the capital investors criteria applied in most selecting the appropriate investment projects, there lies the technology criterion, which Lamarche and Rubinstein (2012) has considered being a primary selection criterion in his conducted study. This technological advantage can be checked through the existing patents list, products' originality, ranking in relation to other competitors as well as the development stage (Kisfalvi, 2003 and Keller et al., 2006). In so for as the present work is concerned, the business selection criterion the company innovation and creativity criterion has been opted for as a major firm selection criterion, depicted in the form of innovation type, along with product uniqueness and specificity. All this leads to formulate the following hypothesis:

H6: The company's creativity and innovation have a positive effect on its funding agreement decision by the venture capital companies.

The following model is used to test the hypothesis:

A multivariate analysis will be undertaken through the following multiple regression analysis, such as:

$$
\begin{gathered}
\text { Rate-Accept }=\beta_{0}+\beta_{1} \text { E-Comp }+\beta_{2} \text { VC-Comp }+\beta_{3} \text { Assistance }+\beta_{4} \text { Capital_Size }+ \\
\beta_{5} \text { Maturity }+\beta_{6} \text { Innov }+\varepsilon
\end{gathered}
$$

As a recapitulation, Table 1 depicts the different variables' relevant definition and measurement, along with their corresponding descriptions.

\subsection{Research variables' measurement}

At this level, each set of variables will be dealt with separately, namely, the variables to explain, the explanatory variables.

\subsubsection{Dependent variable}

It is worth highlighting that the venture capital funded firms are generally characterized with a high risk level (Hisrish et al., 1990; Hatton et al., 1996; Fried and Hisrish, 1994; Floricel et al., 2003 and Dixon, 1991). Indeed, influenced by the potential outcomes' estimates associated with the decision to take, both of the risk perception and assessment procedures might well to be selected for funding by the venture capitalist organism. In fact, attitude regarding risk is subjective and stems partly from direct emotional influences guiding the risk assessment process and the choice of the decision to take (Zacharakis et al., 2007 and Thalmann and Wiedemenn, 2006). With the regard to the venture capital case, risk assessment is mostly based on a set of criteria helping to select the most profitable of the projects (Jeng and Wells, 2000; Fried and Hisrish, 1995 and Wilson et al., 2012). On examining the relevant empirical literature, one could well notice that the selection criteria as used by various venture capitalists do not appear to have the same degree of importance throughout the projects' evaluation phase. Consequently, the probability of accepting the company as a worth funding project turns out to depend largely on the venture capitalist's subjective assessment of the entirety of the applied criteria. Empirically, this probability has its explanation in the so called rate "acceptance" as dependent variable. This variable is defined as a risk threshold rate as determinate by each venture capital companies subject of our study sample, which should not be exceeded for a company to be selected. 


\subsubsection{Independent variables}

Following the already formulated hypotheses, several of the selection criteria determining independent variables have been rejected or omitted. These criteria can be categorized into three major families, each of which could be depicted through a variety set of variables.

Table 1: Variables' identification and measurements

\begin{tabular}{|c|c|c|}
\hline Variables & Definitions & Measurements \\
\hline \multicolumn{3}{|c|}{ Endogenous variable } \\
\hline Rate-Accept & $\begin{array}{l}\text { Acceptance rate } \\
\text { (continuous variable) }\end{array}$ & $\begin{array}{l}\text { This variable is measured by the venture } \\
\text { capitalist' acceptance rate to finance the } \\
\text { enterprise }\end{array}$ \\
\hline \multicolumn{3}{|c|}{ Exogenous variables } \\
\hline \multicolumn{3}{|c|}{ Selection criteria relating to the entrepreneur } \\
\hline E-Comp & $\begin{array}{l}\text { Entrepreneur's professional } \\
\text { competence } \\
\text { (ordinal variable) }\end{array}$ & $\begin{array}{l}\text { This variable is measured by the number } \\
\text { of experience years. }\end{array}$ \\
\hline \multicolumn{3}{|c|}{ Selection criteria relating to the venture capitalist } \\
\hline VC-Comp & $\begin{array}{l}\text { Venture capital professional } \\
\text { competence (continuous } \\
\text { variable) }\end{array}$ & $\begin{array}{l}\text { This variable is measured by the number } \\
\text { of experience years spent in the venture } \\
\text { capital business }\end{array}$ \\
\hline Assistance & $\begin{array}{l}\text { Assistance provided to the } \\
\text { entrepreneur (continuous } \\
\text { variable) }\end{array}$ & $\begin{array}{l}\text { This variable is measured by the } \\
\text { number of days devoted to studding the } \\
\text { project and the number of interviews } \\
\text { and contacts made with the entrepreneur }\end{array}$ \\
\hline \multicolumn{3}{|c|}{ Selection criteria relating to the company } \\
\hline Capital-Size & $\begin{array}{l}\text { Firm capital size } \\
\text { (ordinal variable) }\end{array}$ & $\begin{array}{l}\text { This variable is measured by the } \\
\text { company equity height previously } \\
\text { concluded and sales level turnover }\end{array}$ \\
\hline Maturity & $\begin{array}{l}\text { Company age } \\
\text { (ordinal variable) }\end{array}$ & $\begin{array}{l}\text { This variable is measured by the } \\
\text { enterprise number of experience years }\end{array}$ \\
\hline Innov & $\begin{array}{l}\text { Company creativity and } \\
\text { innovation } \\
\text { (ordinal variable) }\end{array}$ & $\begin{array}{l}\text { This variable is measured by the } \\
\text { company patenting, type of innovation } \\
\text { and product uniqueness }\end{array}$ \\
\hline \multicolumn{3}{|c|}{$\begin{array}{l}\text { With: } \\
\text { Ordinal variable is set to: } \\
\checkmark \quad \text { 1, if the venture capital companies pays no heed to this criterion; } \\
\checkmark 2 \text {, if the venture capital companies attaches little importance to this criterion; } \\
\checkmark \quad 3 \text {, if the venture capital companies attaches moderate importance to this criterion; } \\
\checkmark \quad 4 \text {, if the venture capital companies gives high importance to this criterion; } \\
\checkmark \quad 5 \text {, if the venture capital companies give no opinion. }\end{array}$} \\
\hline
\end{tabular}

\section{RESULTS AND DISCUSSION}

\subsection{Descriptive analysis}

Tables 2 and 3 below depict a summary of the descriptive statistics relevant to both of the continuous and ordinals dependent variables.

It is worth noting that in several previously conducted studies appearing the literature, the entrepreneur's professional quality constitutes the investors' major assessment criterion; Landstrom, 1992 and Zacharakis and Meyer, 2000). Noteworthy, however, is that our attained findings stipulate that the venture capital companies subject of our sample prove to appeal primarily to the company characteristics subject of financing in their assessment process, for instance, the company equity height previously concluded and sales level turnover, jointly grouped under the variable "capital 
size" occupying the first rank. As for the criterion "entrepreneur's professional competence", it ranks fourth among the overall applied criteria. This reached finding is already been confirmed by a respectable number of empirical works stipulating that the entrepreneurial team does not constitute the major criterion for the private equity professionals during the screening filtration stage (Hall and Hofer, 1993 and Kaplan and Stromberg, 2000). The criteria depicted through by the variables "the company's creativity and innovation aspects" and "company's maturity" occupy respectively the 2nd and 3rd ranks.

Table 2: The ordinal variables' descriptive statistics

\begin{tabular}{lcc}
\hline Variables $(\mathbf{N}=\mathbf{4 1})$ & $\begin{array}{c}\text { Average importance accorded by } \\
\text { the venture capital companies }\end{array}$ & Rank \\
\hline E-comp & 3.3 & 4 \\
Capital-Size & 3.94 & 1 \\
Maturity & 3.40 & 3 \\
Innov & 3.46 & 2 \\
\hline
\end{tabular}

As can be noted the sample venture capital companies prove to display an average of 17.5 experience years in the venture capital area, which leads to the deduction that the venture capital domain seems to be quite "young" or new in Tunisia. Concerning the assistance dimension, relating to the number of days denoted by the venture capital companies to study the prospective funding subject project as well as the number contacts and interviewers made with the entrepreneur, it appears to score an average of 30 times.

Table 3: The continuous variables' descriptive statistics

\begin{tabular}{lcccc}
\hline Variables $(\mathbf{N}=\mathbf{4 1})$ & Mean & Std. Dev & Min & Max \\
\hline VC-Comp & 17.5 & 0.227 & 7 & 26 \\
Assistance & 30 & 0.317 & 3 & 15 \\
\hline
\end{tabular}

\subsection{The Multivariate Analysis}

\subsubsection{Matrix of Pearson and multicollinearity}

In Table 4, we provide the Pearson's rho correlations between the variables used in the linear regression.

The most important aspect in the linear regression analysis lies in the multicollinearity problem predominating among the independent variables. According to this table, all correlation coefficients prove to be lower than 0.8 , the threshold at which a serious multicollinearity problem starts to occurs. Furthermore, the "Variance Inflation Factors" VIF have been computed as a means to test the presence of collinearity among the explanatory variables. In all cases, the VIFS are discovered to be lower than 2, bearing in mind that the critical value is set a 10 (Tabachnick and Fidell, 1996). Thus, one might well conclude that the multicollinearity problem is completely non-existent.

Table 4: Pearson correlation matrix and VIF

\begin{tabular}{lccccccc}
\hline N=41 & VIF & E-Comp & VC-Comp & Assistance & Capital_Size & Maturity & Innov \\
\hline E-Comp & 1.7 & 1 & & & & & \\
VC-Comp & 1.85 & $0.048^{* *}$ & 0.0135 & 1 & & & \\
& & -0.262 & $0.224^{*}$ & 1 & & \\
Assistance & 1.45 & 0.374 & 0.062 & 1 & & \\
& & 0.228 & -0.074 & 0.041 & 1 & \\
Capital_Size & 1.10 & 0.294 & 0.752 & 0.276 & 1 & \\
Maturity & 1.78 & -0.375 & 0.049 & -0.095 & 0.572 & 1 \\
\hline
\end{tabular}




\begin{tabular}{|c|c|c|c|c|c|c|c|}
\hline & & 0.154 & 0.821 & 0.163 & 0.256 & & \\
\hline Innov & 1.76 & $\begin{array}{l}0.039 \\
0.469\end{array}$ & $\begin{array}{r}-0.542 \\
0.154\end{array}$ & $\begin{array}{l}0.334 \\
0.342\end{array}$ & $\begin{array}{c}0.196 * \\
0.068\end{array}$ & $\begin{array}{c}-0.398^{*} \\
0.089\end{array}$ & 1 \\
\hline
\end{tabular}

* Correlation significance at the 0.05 level (bilateral), **Correlation significance at the 0.01 level (bilateral)

\subsubsection{Regression analysis}

It is worth noting that the multiple regression model's overall quality lies not only in the regression's significance as a whole, but also in model various parameter, significance in helping to that verify the check each variable's contribution to explain the dependent variable's " Rate-Accept ".

The regression's significance test induces, in its entirety, the following hypotheses:

$\mathrm{H} 0: \beta_{1}=\beta_{2}=\ldots=\beta_{\mathrm{k}}=0$ (no significant contribution is attached to the explanatory variables)

H1: at least one of $\beta$ is different from 0 (at least a single variable displays a significant contribution) The F Statistics (Fischer-Snedecor), as a measure helping to weigh the model's overall significance, allows comparing the importance of the model provided explanation and the residues resultant changes should the model turn out to be correct, the coefficient stemming from the residues' influence would prove to be negligible and the $\mathrm{F}$ value would appear to be too high, thereof.

Based on table5, the Fischer Statistics (F), which is equal to 5.29, is discovered to be significant at the threshold of $1 \%(\mathrm{p}=0.000)$. Hence, the hypothesis $\mathrm{H} 0$ is bound to be rejected, and the regression is estimated to be significant at large.

The quality evaluation of the regression equation's linear fit between the dependent variable and the independent ones is defined through the R-squared determination coefficient, interpreted as the dependent variable's underlying variance percentage, as depicted throwing the model (Shepherd et al., 2002 and Philippe and Geraldine, 2002). As depicted by the same table (Table 5), the determination coefficient seems to equal $85.6 \%$, denoting that $85.6 \%$ of the dependent variable's " Rate-Accept " relating variation has actually been explained by the set of explanatory variables.

As for the adjusted R2, it helps in comprising several multiple regression equations to the same dependent variable, providing their equations prove to differ either by the number of observations, or by the number of explanatory variables. It is crucially interesting to apply $\mathrm{R}^{2}$ adjusted as a quality assessment criterion. Regarding the present study case, the adjusted $\mathrm{R}^{2}$ turns out to be equal to $59.5 \%$, denoting that the different applied variables help contribute with a proportion of $59.5 \%$ in explaining the venture capital companies' acceptance rate to finance companies.

Similarly, table 5 depicts the results of multiple linear regression analysis, along with the impact of each selection criterion applied by the sample pertaining on the acceptance rate to fund the companies as subject of potential funding project.

Table 5: The multiple linear regression's results

\begin{tabular}{lcccc}
\hline \multirow{2}{\text{Independent}}{$\begin{array}{c}\text { Dependent variable "Rate-Accept" } \\
\text { variables }\end{array}$} & Predicted sign & Coef. & Std. Dev. & Sig. \\
\hline Constant & $/$ & 0.879 & 0.210 & 0.000 \\
E-Comp & + & -0.356 & -2.957 & 0.007 \\
VC-Comp & - & -0.239 & -1.859 & 0.075 \\
Assistance & + & -0.232 & -2.031 & 0.053 \\
Capital Size & + & -0.291 & -2.169 & 0.04 \\
Maturity & + & 0.261 & 1.926 & 0.066 \\
Innov & + & 0.408 & 3.011 & 0.006 \\
R-square $\left(\mathrm{R}^{2}\right)=85.6 \%$ & Adjusted R-square $=59.5 \%$ & Fischer $=5.290(\mathrm{P}>\mathrm{F}=0.000) \mathrm{N}=41$ \\
\hline
\end{tabular}




\section{The entrepreneur's professional competence}

On examining the literature, one can well notice that most authors predominantly agree as to considering the entrepreneurial professional quality associated character, which stands as a major criterion fit for evaluating the investment projects with respect to the venture capital professionals (Tyebjee and Bruno, 1984; Lamarche and Rubinstein, 2012; Koonce et al., 2005; Houben, 2002 and Cumming, 2006). As for the other criteria, such as the target market characteristics company size and competitive advantages, they appear to be frequently cited. Several of the empirical studies (Cumming et al., 2008; Cressy et al., 2007; Zacharakis and Meyer, 2000; Sapienza and Gupta, 1994; Schertler, 2003 and Sorensen, 2007) confirm that the investment projects' evaluation, as undertakes by the venture capital professionals, stem from the entrepreneurs themselves, i.e., their capacity to control the business startup and growth as well as their proper technical expertise. Noteworthy, however, is that such a finding seems to be inconsistent with the present research achieved one, in which the entrepreneur's professional competence related criterion proves to occupy the fourth rank in the classification criteria as applied by the venture capital companies' subject of our sample (Table 1). This result has already been confirmed by several previously elaborated research works (Althaus; 2005; Ferrary, 2006; Hall and Hoffer, 1993), highlighting that the entrepreneurial team does not stand as a major criterion in the initial screening phase the main criterion.

In addition, following the multiple linear regression's reached results (Table 5), one can note that the variable "E-Comp" exhibits a negative coefficient (-0.356) despite its significance at the 0.01 level. Indeed, with regard to our sample, the entrepreneur's professional competence appears to negatively affect the venture capital companies' acceptance rate to finance the company. Consequently, the hypothesis $\mathrm{H} 1$ remains invalidated.

The negative relationship binding the dependent variable " Rate-Accept " and the independent variable "E-Comp" reflects the venture capital companies' aversion to the entrepreneur's professional quality. The high level competence of the entrepreneurs allows them to limit their needs with respect to the venture capital companies' investors. Indeed, the least competent of the contractors would opt for to involve the venture capitalist for the sake of risk sharing purposes, while the most competent ones would tend to manage their companies without the need to seek external equity participation not to share so as the power or even the potential benefits (Amit et al., 1990). With respect to the venture capitalist, the entrepreneur turns out to be better informed about the project owing to their privileged access to information and expertise. It is actually this informational asymmetry, associated with a high level of competence, which leads the venture capitalist to face the entrepreneur's risk of opportunistic behavior following the fund providing process. In effect, the extent of the venture capitalist's potential involvement is determined ever since the project selection and evaluation phase, rather than during the post-funding stage. According to Sapienza and Gupta (1994), the venture capitalist's involvement turns out to be highly noticeable whenever the entrepreneur appears to have little expertise.

\section{The venture capital professional competence}

In this respect, and relying on a series of perceived risk measures, Bottazzi et al. (2008), have been led to demonstrate that the wised of managers have tend to display a higher level of risk aversion. Such wisdom has actually been through the director's long term experience. With regard to the venture capital professionals' context, we have considered, as a measure of the venture capital companies' professional competence, the number of experience spent by the venture capital organization in caring out this business, this we have been able to formulate the hypothesis $\mathrm{H} 2$.

The indicated variable exhibits a negative coefficient $(-0,239)$ and proves to be significant at the threshold of $10 \%$. It is actually the negative relationship noticed to occur between this variable and the dependent variable "Rate-Accept" which leads to accept the hypothesis H2.

Indeed, experience seems to stand as a significant determinant in concluding contracts regardless of the development stage. As a matter of fact, an experienced venture capitalist may well resort to using contracts granting them more rights in case of poor performance, to shield against any possible interest 
conflict risks (Brophy and Haessler, 1994 and Cochrane, 2005). With regard to our study case, one can note that the most experienced of the venture capital companies appear to be rather reserved as to the investment opportunities, with their experience scope proving to negatively affect the recourse to the risk mitigating mechanisms. Hence, the most experienced venture capitalists are discovered to be less likely to use the contractual practices and protection tools safeguarding them against any potential adverse selection risk likely to emanate from any potentially funded projects. Such a finding has already been confirmed by Cumming (2006) as well as De Clercq et al. (2001).

The pertinent literature suggests that through experience, venture capitalists prove to be developing a professional mechanism whereby they could assess and select the most convenient of the projects, on the ground that their potential participation would turn out to be too risky and little liquid (Desbrières, 2001). Practically, however, instead of proceeding with a systematic evaluation of every project's single aspect to help reduce the risk of any inconvenient selection, the venture capitalists turn to rather appeal to an intuitive and subjective assessment, likely to stand as the major bone of contention between the venture capitalist and the entrepreneur (De Clercq and Dimov, 2004 and Desbrières and Broye, 2000).

\section{The venture capitalist /entrepreneur assistance procedure}

Relying on Fluck et al. (2005) advanced suggestion, it is estimated that the initial interactions between two parties would have a positive influence on trust allocation. With regard to the venture capital funding context, we undertake to the venture capitalist and entrepreneur interaction's influence on the probability of accepting the subject company as a fund deserving project. In this respect, the variable "Assistance" is assessed through the number of contact shield between the two parties along with the number of days denoted to studying the financing proposal, and it proves noticeably is significant at the threshold of $10 \%$, while the relating coefficient appears to be negative $(-0.232)$. Such a result implies that the amount of information processed by the investor during interactions with the contractor and at the study of the file turns out to be insufficient and cannot be regarded as a source of improving the relationship between both parties. Hence, the hypothesis $\mathrm{H} 3$ turns out to be invalidated.

Such a finding reveals well that the venture capital companies subject of the sample does not appear to pay much trust in the information collected through the investment project relevant files. Throughout the project selection phase, the venture capitalist is faced with a kind of information asymmetry related problem, as the contractor does actually withhold greater information concerning the company's real characteristics and its environment. As a matter of fact, this problem could well bring about an adverse selection situation (Desbrieres and Hommel, 2006) and risks to result in formulating poor estimates as to the project's development potential (Akerlof, 1970 and Jeng and Wells, 2000).

Most often, the high-tech and communications sector tends to exhibit a wide range of projects characterized with remarkable uncertainty and lack of historical information (Amit et al., 1998 and Gompers, 1995). Faced with an adverse selection risk, the venture capitalist is expected to adopt a responsively active attitude all over the selection phase, in a bid to reduce the information asymmetry as a favoring source of such a risk. For the sake of reducing these problems, the venture capitalists resort to undertaking a business plan study. In doing so, they could well manage to produce expertise information likely to help them eliminate the least attractive of the projects and select those with an a priori satisfactory profitability (Hege et al., 2009 and Jeng and Wells, 2000).

\section{The firm's capital size}

In this study context, no direct reference to a particular study or author has been made for the purpose of testing or validating hypothesis. We simply aim to examine the company's capital size, as measured through the concluded past sales' level (turnover), along with its assets' rate, on the venture capital companies' acceptance rate to finance the business. 
On the basis of the multiple linear regression reached results, the variable "Capital_Size" turns out to have a negative effect on the venture capital companies' acceptance rate to finance the company (with a respective negative coefficient (-0.291). It seems that, in regard of our study sample, the firm's capital size relevant criterion proves to have a negative effect the acceptance rate to finance the subject company, a finding which appears to contradict the results achieved by Kut et al. (2005) and Leleux and Surlemont (2003). Consequently, the hypothesis H4 remains no-validated.

This result might well be due to the fact that through the data collection process, and will respect to the newly set-up companies' case, it has been discovered that some investors tend to accord greater importance to the weakly few recorded sales (Rank 1 in Table 1) insofar as they stand as a token of the executive's skill and marketing strategy which, one added to the persistence of a respectably important policy leader, initial capital, can well reassure the venture capital professionals confidence, as already expressed by other parties, as well as the founder's proper network (Lerner and Schoar, 2005). As for the achieved empirical results, it is worth noting that this criterion imposes a negative impact on the venture capital companies' attitude as to the subject company. Such a finding seems quite surprising, as we would systematically expect to real a favorable influence of a pre-existing business trend or ever a high equity level. This result might well have its explanation in the fact that this financial criterion does not actually constitute a reliably deterministic evalvasionary criterion, in itself. Besides, the venture capital companies' management team does not strongly believe that the founder does actually have a decisive power within the company. This allows us to highlight the venture capital's constraint towards the control of the entrepreneur as well as the interest conflicts.

\section{The firm's maturity stage}

With respect to the present work, company maturity is assessed through the company's registered age. So the latter's possible influence on the company's assessment by the venture capital companies will be treated in this section. It has been presumed that most nature of the companies would display a higher profile and lower risk to be taken by the investor, and would, therefore, be rather liable for funding (Jengfang et al., 2012). Hence, based on the reached multiple linear regressions' results, the variable "Maturity" turns out to be significant at the threshold $10 \%$, with a positive relevant coefficient (0.261). Thus, the company's maturity impact on its acceptance rate to be funded by the venture capital companies does prove to be positive. The hypothesis $\mathrm{H} 5$ appears to be validated.

Companies appealing to venture capital organisms for funding are generally characterized with a highly risky structure, along with the persistence of too formalized information, owing to the fact that they are not constrained by legal information communication and diffusion rules or regulations. The advanced development stage provides the venture capitalist with a rather reliable source of managerial professional quality throughout the different evolution stages, whereas the newly established companies, with too low accounting information, help in increasing the venture capitalist incurred risk owing mainly to the executive's manipulation of information disclosed, which renders its follow up process a too difficult procedure (Goergen et al., 2011). The venture capital companies' reservation as to financing the recently set up business, due to lack or even poor information leads to a restriction the venture capital's intervention scope and reduces the opportunity extent of several promising projects in need for financial resources and for a trust worthy investor confident in their potentially prospective economic development.

\section{The firm's creative and innovative aspect}

Specialized investors of a venture capital type enjoy technical and scientific expertise allowing them to effectively select and monitor the projects' development process and to predominantly target companies satisfying certain specific characteristics, usually those developing innovations in hightech sectors and exhibiting a highly important the expected performance. Such enterprises make the venture capital companies optimistic about concluding significant gains on releasing funds (Mathieux 1993 and Manigart et al., 2006). It is in this context that the hypothesis H6 has been formulated. 
In this study, the appropriate criterion considered to measure the variable "Innov" has been: patenting, innovation type along with the product's unique and specific nature. For the purpose of testing such a hypothesis, a multiple linear regression analysis has been applied, which yielded a relative significance below 0.01 , with a positive associated coefficient (0.408). Such a finding denotes well that the company's creative and innovative aspect does prove to have a positive effect on the venture capital companies' funding acceptance rate. The hypothesis H6 proves, therefore, to be validated. Concerning our particular study case, and based on the multiple linear regression and on the different criteria classification in order of importance (Rank 2 of Table 1), the projects' innovation and growth potential appear to stand as a fundamentally funding motivating and represents a remarkable guarantee for acquiring the so difficult to imitate competitive advantage. This result has already been confirmed by the previously elaborated research works conducted by (Ljungqvist and Richardson, 2003; Manigart et al., 1997; Mason and Harrison, 2004, Murray and Marriott, 1998 and Phalippou, 2009).

\section{CONCLUSION}

The present study has been focused on a thorough examination of the Tunisian corporate case financing strategy as undertaken by the venture capital institutions. For a thorough analysis of some criteria applied during the selection process likely to the entrepreneur's professional competence, the venture capital professional competence, the venture capitalist /entrepreneur assistance procedure, the firm's capital size, the firm's maturity stage and the firm's creative and innovative aspect, are imposed.

Relying on a sample of 41 venture capital institutions, a multiple linear regression estimate has been undertaken.

The multiple linear regressions' results have shown that the firm's maturity stage and the firm's creative and innovative aspect positively related with the venture capitalist' acceptance rate to finance the enterprise "Rate-Accept". In addition, a negative relationship has been discovered to persist between "Rate-Accept" and both of the venture capital professional competence, the venture capitalist /entrepreneur assistance procedure and the firm's capital size. This results help reflects the venture capital companies' aversion to the decisive power the contractor might have. Besides, a significant level of equity and company turnover may also lead to reducing the investing organization's chances to have access to the decisive power in the company and control the executive, for its participation would be restricted to just satisfying the financial needs. Nevertheless, a financial intervention of such an investment is supposed to be jointly accompanied with other inputs or contributions in terms of advice, knowledge, competences and assistance support, owing to the investor's experiences with different companies and in the venture capital affairs' area. In effect, the venture capital companies' prospective strategy and future vision have to be formulated on the basis of mutual collaboration with the contractor for the sake of reducing the opportunistic behavior related issues and maximizing the company value and maintain the achievement of more added values on withdrawing participation in the business capital. The concept of the venture capitalist / entrepreneur relationship under the agency theory, as applied in the company, should be supported by the theory that maintains safeguarding knowledge exchange and transfer among both of the involved. As a matter of fact, the in-capital investor approach should, therefore, be rather operational in formulating the appropriately fit strategy, through the investors' disposition to provide management with the necessary skills, knowledge as well as their maintained professional relationships responding to the financial needs. In this respect, one could recall the cognitive relationship likely to persist between the capital investor and the entrepreneur.

Despite the crucial importance of the achieved results, our study bears certain limitations. Firstly, the size of our study sample is quite small (41venture capitalist). Secondly, there are another criterion can be incorporated on this study.

Despite these limitations, the results achieved by this study seem to be potentially useful to entrepreneurs as well as outsider investors. 
Funding: This study received no specific financial support.

Competing Interests: The authors declare that they have no competing interest.

Contributors/Acknowledgement: All authors participated equally in designing and estimation of current research.

Views and opinions expressed in this study are the views and opinions of the authors, Asian Journal of Empirical Research shall not be responsible or answerable for any loss, damage or liability etc. caused in relation to/arising out of the use of the content.

\section{References}

Akerlof, G. (1970). Market for lemons: Qualitative uncertainly and the market mechanism. Journal of Economics, 84, 488-500. view at publisher

Alexander, P., \& Peter, R. (2013). Venture capital and new business creation. Journal of Banking and Finance, 37(12), 4695-4710. view at Google scholar / view at publisher

Althaus, C. F. (2005). A disciplinary perspective on the epistemological status of risk. Risk Analysis, 25(3), 567-588. view at Google scholar / view at publisher

Amit, R., Brander, J., \& Muller, E. (1990). Entrepreneurial ability venture investments and risk sharing. Management Science, 36, 1232-1254. view at Google scholar / view at publisher

Amit, R., Brander, J., \& Zott, C. (1998). Why do venture capital firms exist? Theory and canadian evidence. Journal of Business Venturing, 13, 441-466. view at Google scholar / view at publisher

Barney, J. B., Bousenitz, L. W., Moesel, D. D., \& Fiet J. O. (1994). The relationship between venture capital and managers in new firms: determinants of contractual covenants. Managerial Finance, 20, 111-120. view at Google scholar / view at publisher

Bechmann, C., Burton, M. D., \& O’Reilly, C. (2007). Early teams: the impact of team technology on $\mathrm{VC}$ financing and going public. Journal of Business Venturing, 22(2), 147-173. view at Google scholar / view at publisher

Bottazzi, L., Da Rin, M., \& Hellmann, T. (2008). Who are the active investors? Evidence from venture capital. Open Access publications from Tilburg University. view at Google scholar / view at publisher

Brophy, D. J., \& Haessler, M. R. (1994). The venture capital fund agreement, Managerial capital. Entrepreneurship: Theory \& Practice, 30(2), 155-183.

Cochrane, J. (2005). The risk and return of Venture capital. Journal of Financial Economics, 75, 352. view at Google scholar / view at publisher

Cressy, R., Munari, F., \& Malipiero, A. (2007). Playing to their strengths? Evidence that crowding out? A pan European analysis. Journal of Business Venturing, 18(1), 81-104. view at Google scholar

Cumming, D. (2006). Adverse selection and capital structure: evidence from venture capital. Entrepreneurship: Theory \& Practice, 30(2), 155-183. view at Google scholar / view at publisher

Cumming, D., Fleming, G., \& Schweinbacher, A. (2008). Financial intermediaries, ownership structure and monitored finance: evidence from Japan. Small Business Economics, 31(1), 5992. view at Google scholar / view at publisher

Cyr, A. (2008). Risk perception in the perspective of venture capital companies and innovative SMEs: an exploratory study. Proceedings of the 9th CIFEPME, Louvain-la-Neuve, Belgium, 28 - 31 October.

De Clercq, D., \& Dimov, D. (2004). Explaning venture capital firms' syndication behaviour: a longitudinal study. Venture Capital, 6(4), 243-256. view at Google scholar / view at publisher

De Clercq, D., Goulet P. K., Kumpulainen, M., \& Makela M. (2001). Portfolio investment strategies in the Finnish venture capital industry: A longitudinal study. Venture Capital, 3(1), 41-62. view at Google scholar / view at publisher

Desbrières, P. (2001). The capital-investment relationship in industrial and commercial firms. Working Papers FARGO, No1000502.

Desbrières, P., \& Broye, G. (2000). The evaluation criteria of capital investors: the French case. Finance Contrôle and Stratégie, 3, 5-43. 
Desbrieres, P., \& Hommel, U. (2006). Why do European venture capital companies syndicate? Entrepreneurship Theory and Practice, 30, 2, 131-153. view at Google scholar

Dimov, D., Shepherd, D. A., \& Sutcliffe, K. M. (2007). Requisite expertise, firm reputation and status in venture capital investment allocation decision. Journal of Business Venturing, 22, 481-502. view at Google scholar / view at publisher

Dixon, R. (1991). Venture Capitalists and the Appraisal of lnvestments. OMEGA International Journal of Management Science, 19(5), 333-344. view at Google scholar / view at publisher

Ferrary, M. (2006). Collaborative learning and networks of venture capitalists. French Journal of Management, 32(163), 171-182.

Finucane, M. L., Alhakami, A., Slovic, P., \& Johnson, S. M. (2000). The affect heuristics in judgement of risks and benefits. Journal of Behavioural Decision Making, 13, 1-17. view at Google scholar

Floricel, S., \& ST-Pierre, J. (2003). Evaluating risk in the innovation projects of small firms. Proceedings of the Annual Conference of the Administrative Sciences Association of Canada. Strat Technology and Innofavion Management Division, Halifax, Nova Scotia, June 14-17, http://www.asac.ca/asac-f.htm.

Fluck, Z., Garrison, K., \& Myers, S. (2005). Venture capital contracting and syndication: French year. Finance, Control and Strategy, 3(3), 5-43. view at publisher

Franzke, S. A. (2004). Underpricing of venture-backed and non venture-backed IPOs: Germany's Neuer Markt. In the rise and fall of Europe's new stock markets, edited by G. Giudici and P. Roosenboom. Elsevier Science, Oxford Freel, 2007. view at Google scholar / view at publisher

Fried, V. H., \& Hisrish, R. D. (1994). Toward a model of venture capital investment decision making. Financial Management, 33(3), 28-37. view at Google scholar / view at publisher

Fried, V. H., \& Hisrish, R. D. (1995). The venture capitalists: a relationship investor. California Management Review, 37(2), 101-113. view at Google scholar

Goergen, M., O'Sullivan, N., \& Wood, G. (2011). Private equity take overs and employment in the UK: some empirical evidence. Corporate Governance: An International Review, 19(3), 259275. view at Google scholar / view at publisher

Gompers, P. A. (1995). Optimal investment, monitoring, and the staging of venture capital. The Journal of Finance, 50(5), 1461-1489. view at Google scholar / view at publisher

Hall, J., \& Hoffer, C. W. (1993). Venture capitalists' decision criteria in new venture evaluation. Journal of Business venturing, 8(1), 25-42. view at Google scholar / view at publisher

Hatton, L., \& Moorehead, J. (1996). Determining venture capitalist criteria in evaluating new ventures. http://www.sbaer.uca.edulresearchlusasbe/1996/pdf/07.

Hege, U., Palomino, F., \& Schwienbacher, A. (2009). Venture Capital Performance: The Disparity between Europe and the United States. Revue Finance, 30(1), 7-50. view at Google scholar / view at publisher

Hisrish, R. D., \& Jankowicz, A. D. (1990). Intuition in venture capital decisions: an exploratory study using a new technique. Journal of Business venturing, 5(1), 49-62. view at Google scholar / view at publisher

Houben, H. (2002). Venture capital doubles side's adverse selection and double side's moral hazard. Working Paper. University of Kiel. view at publisher

Jeng, L., \& Wells, P. C. (2000). The determinants of venture capital funding: evidence across countries. Journal of Corporate Finance, 6, 241-289. view at publisher

Jengfang, Ch., Woody, M., \& Lu, C. (2012). The effects of public venture capital investments on corporate governance: Evidence from IPO Firms in emerging market. Journal of Accounting Finance and Business Studies, 48, 86-103. view at Google scholar / view at publisher

Jennifer, J. R., Henock, L., \& Dahlia, R. (2009). Managers and investors: responses to media exposure of board ineffectiveness. Journal of Financial and Quantitative Analysis, 44(3), 579-605. view at Google scholar / view at publisher

Justine, E. T., Kjersten, B. W., Manwai, C. K. U., \& Andrea, R. D. (2015). Gender and Venture capital decising-making: the effects of technical background and social capital entrepreneurial evaluations. Social Science Research, 51, 1-16. view at Google scholar / view at publisher 
Kaplan, S., \& Stromberg, P. (2000). Financial contracting theory meets the real world: an empirical analysis of venture capital contracts. Working Paper, $\mathrm{N}^{\circ} 7660-\mathrm{NBER}$. view at Google scholar I view at publisher

Keller, C., Siegrist, M., \& Gutscher, H. (2006). The role of the affect and availability heuristics in risk communication. Risk Analysis, 26(3), 631-639. view at Google scholar / view at publisher

Kisfalvi, V. (2002). The entrepreneur's character, life issues and strategy making. A field study. Journal of Business Venturing, 17,489-518. view at Google scholar / view at publisher

Kisfalvi, V. (2003). Doing what feels right. The influence of CEO character and emotions on top management team dynamics. Journal of Management Inquiry, 12(1), 42-66. view at Google scholar

Koonce, L., Brun, W., \& Johnsen, B. H. (2005). Risk as feeling or risk and feelings? A cross-Iagged panel analysis. Journal of Risk Research, 8(5), 417-437.

Kut, C., Pramborg, B., \& Smolarski, J. (2005). Risk management in European private equity funds: survey evidence. Journal of Private Equity, 9, 42-54.

Lamarche, T., \& Rubinstein, M. (2012). Dynamics of corporate social responsibility: towards a new conception of control?. Journal of Institutional Economics, issue 8(2), 161-186. view at Google scholar / view at publisher

Landstrom, H. (1992). The relationship between private investors and small firms: an agency theory approach. Entrepreneurship and Regional Development, 4(3), 199-223. view at Google scholar I view at publisher

Leleux, B., \& Surlemont, B. (2003). Public versus private venture capital: seeding or crowding out? A pan European analysis. Journal of Business Venturing, 18(1), 81-104. view at Google scholar

Lerner, J., \& Schoar, A. (2005). Does legal enforcement affect financial transactions? The contractual channel in private equity. Quarterly Journal of Economics, 120(1), 223-246. view at Google scholar / view at publisher

Ljungqvist, A., \& Richardson, M. (2003b). The investment behaviour of private equity fund managers. Working Paper No 005, RICAFE, (Risk Capital and the Financing of European Innovative Firms. view at Google scholar / view at publisher

MacMillan, I. C., Siegel, R., \& Subba Narasimha, P, N. (1985). Criteria used by venture capitalists to evaluate new venture proposals. Journal of Business venturing, 1(1), 119-128. view at Google scholar / view at publisher

MacMillan, I., Zemann, L., \& Subbanarasimha, P. (1987). Criteria distinguishing successful from unsucessful venture screening process. Journal of Business Venturing, 2(2), 123-137. view at Google scholar / view at publisher

Mathieux, X. (1993). Private equity and value of the company. Bank, no538.

Manigart, S., Wright, M., Robbie, K., Desbrieres, P., \& Waele, K. D. E. (1997). Venture Capitalists' Appraisal of Investment Projects: An Empirical European Study. Entrepreneurship Theory and Practice, 21(4), 29-43. view at Google scholar

Manigart, S., Lockett, A., Meuleman, M., Wright, M., Landstrom, H., Bruining, H., Desbrieres, P., \& Hommel, U. (2006). Why Do European venture capital companies syndicate? Entrepreneurship Theory and Practice, 30(2), 131-153. view at Google scholar

Mason, C., \& Harrison, R. (2000). Venture capital market complementarities: The links between business angels and venture capital funds in the United Kingdom. Venture Capital: An International Journal of Entrepreneurial Finance, 2(3), 223-242. view at Google scholar / view at publisher

Mayer, C., Schoors, K., \& Yafeh, Y. (2005). Source of funds and investment strategies of venture capital fund. Working paper N 9645, national bureau of economic research. view at Google scholar

Murray, G. C., \& Marriott, R. (1998). Why has the investment performance of technologyspecialist, European venture capital funds been so poor?. Research Policy, 27, 947-976. view at Google scholar / view at publisher

Myers, C., \& Majluf, S. (1984). Corporate financing and investments decisions when firms have information's that investors do not have. Journal of Financial Economies, 13(3), 187-221. view at Google scholar / view at publisher 
Pagano, R., \& Volpin, P. (2005). Managers, workers and corporate control. Journal of Finance, 60(2), 841-868. view at Google scholar / view at publisher

Phalippou, L. (2009). Venture capital funds: Flow-performance relationship and performance persistence. Journal of Banking and Finance, 3, 568-577. view at Google scholar / view at publisher

Philippe, D., \& Géraldine, B. (2002). Criteria for assessing capital investors: the French case. Finance Control Strategy, 3, 3-43.

Rosenbush, N., Brinkmann, J., \& Muller, V. (2013). Does acquiring venture capital pay off for funded firms? A meta-analysis on the relationship between venture capital investment and funded firm financial performance. Journal of Business venturing, 28, 335-353. view at Google scholar

Sapienza, H. J., \& Gupta, A. K. (1994). Impact of Agency Risks and Task uncertainly on Venture Capitalist-CEO interaction. Academy of Management Journal, 37(6), 1618-1632. view at Google scholar

Schertler, A. (2003). Driving forces of venture capital investments in Europe: a dynamic panel data analysis. Working Paper, Kiel Institute for World Economics, no 1172. view at Google scholar

Shepherd, D. A., \& Zachrakis, A. (2002). Venture capitalists' expertise a call for research into decision aids and cognitive feedback. Journal of Business venturing, 17(1), 1-20. view at Google scholar

Sorensen, M. (2007). How smart is smart money? a two-sided matching model of venture capital. Journal of Finance, 62, 2725-2762. view at Google scholar / view at publisher

Stevenot, A. (2006). Conflicts in the capital-investor-manager relationship: an analysis in terms of cognitive governance. French Management Review, 164, 157-180.

Stiglitz, J. E., \& Weiss, A. (1981). Credit rationing in market with imperfect information. American Economic Review, 71(3), 393-410. view at Google scholar

Tabachnick, B. G., \& Fidell, S. J. (1996). Using multivariate statistics. Boston, MA: Pearson. Tabachnick, Fidell, and Osterlind, 1996. view at publisher

Thalmann, A. T., \& Wiedemenn, P. M. (2006). Beliefs and emotionality in risk appraisals. Journal of Risk Research, 9(5), 453-466. view at Google scholar

Tyebjee, T. T., \& Bruno, A. V. (1984). A model of venture capitalist investment activity. Management science, 30(9), 1051-1066. view at Google scholar

Wilson, N., Wright, M., Siegel, D. S., \& Scholes, L. (2012). Private equity portfolio company performance during the global recession. Journal of Corporate Finance, 18, 193-205. view at Google scholar / view at publisher

Wood, G., \& Wright, M. (2010). Private equity and human resource management: an emerging agenda. Human Relations, 63(9), 1279-1296. view at Google scholar / view at publisher

Wright, M., Gilligan, J., \& Amess, K. (2009). The economic impact of private equity: what we know and what we would like to know?. Venture Capital, 11(1), 11-21. view at Google scholar

Wright, M., \& Robbie K., (1996). Venture capitalists, unquoted equity investment appraisal and the role of accounting information. Accounting and Business Research, 26(2), 153-177. view at Google scholar / view at publisher

Yan, A., Georges, H., \& Fabrice, L. (2015). How does govermental versus private venture capital backing affect a firm's efficiency? Evidence from Belgium. Journal of Business Venturing, 30(4), 508-525. view at Google scholar / view at publisher

Zacharakis, A. L., \& Meyer, G. D. (1998). A lack of insight: do venture capitalists really understand their own decision process? Journal of Business Venturing, 13(1), 57-76. view at Google scholar / view at publisher

Zacharakis, A. L., Mcmullen, J. S., \& Shepherd, D. A. (2007). Venture capitalists' decision policies across three countries: an institutional theory perspective. Journal of International Business Studies, 38, 691-708. view at Google scholar / view at publisher

Zacharakis, A., \& Meyer, G. D. (2000). The potential of actuarial decision models: can they improve the venture capital investment decision? Journal of Business venturing, 15, 323-346. view at Google scholar

Zopounidis, C. (1987). Venture capital in France: The companies financed. The Financial Review, 52, 39-49. 